\title{
Slovanska filologija v dialogu med Matijem Murkom in Jiř́ijem Polívko
}

\author{
Anna Zelenková \\ Slovanský ústav Akademie věd České republiky, Valentinská 91/1, \\ CZ-11000 Praha-Staré Město, zelenkova@slu.cas.cz
}

Alenka Jensterle-DoležAl

Univerzita Karlova v Praze, Filozofická fakulta, Nám. Jana Palacha 2, CZ-11638Praha 1, dolezalova.l@volny.cz

\begin{abstract}
Vzajemna korespondenca dveh velikih evropskih slavistov na prelomu 19. in 20. stoletja, M. Murka (1861-1952) in J. Polívke (1858-1933) razkriva bogato znanstveno sodelovanje $\mathrm{v}$ srednjeevropskem prostoru, ko so se na obrobnih področjih habsburške monarhije povezovale slavistične filološke raziskave z narodnim gibanjem in s kulturno-političnimi ambicijami. Odnos, ki je temeljil na izmenjavi idej in medsebojni inspiraciji, je zaznamoval delo in življenje tako češkega kot slovenskega znanstvenika. $\mathrm{V}$ pismih sta se posvečala novi podobi univerzitetnih slavistik v Pragi in na Dunaju, razmišljala sta o neuresničeni možnosti osnovanja slovenske fakultete na Karlovi univerzi v Pragi.
\end{abstract}

The paper explores relations between two major Slavonic scholars in Europe at the turn of the $20^{\text {th }}$ century: M. Murko (1861-1952) and J. Polívka (1858-1933). Based on a careful study of their correspondence, it particularises their fruitful collaboration in the area of Central Europe at the time when the advancement of Slavonic studies in the peripheral regions of the Hapsburg Empire brought together philological research and national revival as well as cultural and political ambitions. The relationship between the two men, as it was naturally fostered through the exchange of ideas and mutual inspirations, had a significant impact on their personal and professional careers. Their letters deal with the institutional history of Slavonic studies, referring to the newly-built Departments of Slavonic Studies in Prague and Vienna, and to the failed initiative to establish the Slovenian Faculty at Charles University, Prague.

Ključne besede: zgodovina slavistike, znanstvena korespondenca, Matija Murko, Jiří Polívka, slovensko-češki odnosi

Key words: history of slavistics, correspondence between slavists, Matija Murko, Jiří Polívka, Slovene-Czech relations. 
Polívka se je seznanil z Murkom na začetku devetdesetih let 19. stoletja. Njun delovni odnos se je posebno okrepil leta 1920, po Murkovem prihodu v medvojno Češkoslovaško in je trajal vse do Polívkove smrti leta 1933. Polívka mu je v letih 1890-1914 poslal šestindvajset pisem, Murko pa mu jih je v času med 1890 in 1928 petinštirideset. ${ }^{1}$ Zanimiva je tudi izbira jezika za dopisovanje, ki kaže na tedanjo uveljavljeno predstavo vsestranskega znanstvenika slavista. Murko je Polívki pisal v slovenščini (samo nekatera njegova kasnejša pisma so v nemščini in češčini), s tem da se mu v slovenski jezik (pod vplivom nemškega okolja) vriva nemščina:

Upam, da bo vam mogoče slovensko pismo razumeti. Sploh je najbolje za nas filologe, da se vsak na svojem jeziku dopisujeme, kar skupni ali bolje diplomatični jezik se še ne bo tako skoro ustanovil. ${ }^{2}$

Polívka mu je odgovarjal v češčini.

Murko je bil profesor slovanske filologije v Gradcu (1902-1917) in Leipzigu (1917-1920) in profesor južnoslovanskih jezikov in filologij v Pragi (1920-1931). Čeprav je najprej deloval na avstrijskih univerzah, je bila za Murka povezava s češkimi znanstveniki zelo pomembna. Zveze so se še okrepile med pisanjem in po izdaji njegove prve knjige z bohemistično tematiko $1897 .{ }^{3}$ Knjigo so pozitivno ocenili tudi češki znanstveniki. Polívka je bil od Murka le nekaj let starejši, aktivno je deloval tako v univerzitetnih krogih kot v češki kulturi. Njun dialog je bil tudi pomemben slavistični kontekst: ne samo na avstrijskih univerzah oziroma v nemškem prostoru, tudi na praški Filozofski fakulteti se je uspešno razvijala slavistika in v tem obdobju so se znotraj nje oblikovale nove bohemistične panoge. Češka slavistika je v bila v okviru slovensko-čeških odnosov za Slovence še posebno pomembna: na Češkem so že v 19. stoletju nastajali tudi prvi pregledi zgodovine slovenske literature v okviru južnoslovanskih raziskav, ${ }^{4}$

${ }^{1}$ Primerjaj Jan Vagner, Matija Murko, Praga, 1963 (edicija inv. št. 87); Jarmila Mourková, Redakční korespondence časopisu Slavia, Praga, 1964 (edicija inv. št. 174); primerjaj tudi geslo Murko, Matija, v: Katalog rokopisov narodne in univerzitne knjižnice v Ljubljane, Ljubljana 1980, 51-70 (št. sign. Ms 1119 in Ms 1392); Eva Pavlásková in František Bat'ha: Jiři Polivka. Praga, 1959 (edicija inv. št. 100). Korespondenca M. Murka, naslovljena na J. Polívko, se nahaja v praškem Literarnem arhivu (Literární archiv Památníku národního písemnictví (LA PNP) na Strahovu: fond M. Murko, 45 pisem, dopisnic in razglednic, razdeljenih na tri spise: 15/B/26 - 15 enot od 1890 do 1906, 6/X/26 - 15 enot od 1906-1915, 6/A/26 - 15 enot od 1913 do 1928. Prvo dopisnico je Murko napisal Polívki 18. 8. 1890 in zadnje pismo takrat že bolnemu korespondentu 28. 11. 1928.

${ }^{2}$ Murko Polívki v pismu iz Dunaja, 18. 8. 1890. Nahaja se v Literárním archivu Památníku národního písemnictví (LA PNP) na Strahovu: fond M. Murko, 15/B/26.

${ }^{3}$ Mathias Murko, Deutsche Einflüsse auf die Anfänge der slavischen Romantik I. Die böhmische Romantik. Mit einem Anhang: Kollár in Jena und beim Wartburgsfest, Graz 1897, XII + 373 s.

${ }^{4}$ Murko je kot prvi slovenski avtor napisal znanstveno poglobljeno študijo o slovenskem jeziku, literaturi in kulturi za Ottův slovnik v Pragi, ki je bil največji češki enciklopedični projekt na koncu 19. in na začetku 20. stoletja v Pragi (Jensterle-Doležal 2005a: 24-38). 
Praga je bila v tem obdobju še vedno razumljena kot zibelka slovanstva, kot rojstno mesto Kollárjeve ideje o slovanski vzajemnosti. ${ }^{5}$

Polívka (1858-1933) je bil eden od najbolj znanih slovanskih filologov in slavistov, pozneje profesor slovanskih literatur na Filozofski fakulteti Karlove Univerze v Pragi. Tudi on je bil tako kot Murko na začetku jezikoslovec: pod vlivom svojega učitelja Jana Gebauerja se je usmerjal v lingvistiko oz. slovnico slovanskih jazikov, preučeval pa je tudi slovaško in južnoslovansko dialektologijo. Pozneje je - podobno kot Murko - prešel na primerjalno raziskovanje slovanskega ljudskega slovstva, predvsem pravljic. Od leta 1903 je urejal Narodopisní sborník, ki ga je pozneje preimenoval v Národnopisný věstník. ${ }^{6}$ Polívka in Murko sta si pošiljala tiskovine in izvlečke svojega dela, priporočala sta si strokovno literaturo, vzajemno diskutirala o vprašanjih, ki so bila predmet njunih znanstvenih raziskav, živo pa sta tudi izmenjavala mnenja o položaju slovanske filologije na univerzah, kjer sta delovala. Iz njune korespondence postaja jasen tudi njun skupni cilj - razvijati slovansko filologijo kot samostojno vedo in jo izločiti iz področja narodne mitologije in nacionalističnega novinarstva. Polívka je že leta 1902 vabil Murka med sodelavce svojega časopisa Věstník. Podobno mu je leta 1908 tudi Murko kot eden izmed urednikov mednarodne znanstvene revije Wörther und Sachen ponujal možnost objave v reviji. Njuna bibliografija $^{7}$ kaže na to, da sta oba slavista spremljala profesionalni razvoj drug drugega, da sta se recenzirala in moralno podpirala tudi v prizadevanjih dobiti stalno mesto docenta in izrednega profesorja.

Iz pisem se vidi, da je na tleh avstroogrske monarhije med malimi slovanskimi narodi na koncu 19. in začetku 20. stoletja, podobno kot v razsvetljenskem in romantičnem obdobju narodnega prebujanja in »slovanske« solidarnosti, med znanstveniki obstajala mreža znanstvenega sodelovanja. Najbolj intenzivno sta si pisala na začetku znanstvene poti: na koncu 19. in na začetku 20. stoletja, ko je bil Murko na Dunaju in pozneje v Gradcu in Polívka v Pragi. Takrat se je Murko živo zanimal za razvoj bohemistike in slavističnih študij v Pragi ter pisal in komentiral dogajanje na slavistiki na Dunaju in v Gradcu, Polívka pa se je z Murkom posvetoval o novi podobi praške slavistike.

Obsežna korespondenca med generacijsko in delovno povezanima znanstvenikoma se je začela leta 1890, ko je Murko poslal Polívki (preko ruskega slavista Speranskega) separat svoje monografske študije Die Geschichte von den sieben Weisen bei der Slawen (Dunaj 1890). ${ }^{8}$ Murkov tekst je bil rezultat

\footnotetext{
${ }^{5}$ Murko je večkrat razmišljal o Kollárjevem delu in ga tudi večkrat interpretiral, slovansko vzajemnost je razumel v širšega kulturnega in duhovnega sodelovanja (primerjaj Jensterle-Doležal 2005b: 136-148).

${ }^{6}$ Národopisný věstník českoslovanský, 1906-1953. Glavni znanstveni časopis za slovansko slovstveno folkoristiko, ki se je ukvarjal z narodopisjem v povezavi s sorodnimi vedami. Poleg Polívke je bil med uredniki tudi Pastrnek.

${ }^{7}$ Bečka, Zelenková 2003: 124-168; primerjaj tudi bibliografijo Jiř́ Polívka (1858-1933), ur. Gašparíková, 2006.

${ }^{8}$ Primerjaj Bečka, Zelenková 2003: 124-168.
} 
njegovega študijskega potovanja v Rusijo. Analitično razlago rokopisov je povezal z zgodbo o sedmih modrijanih. V delu je izpostavil izvirne teze o motivni in strukturni transformaciji pripovedke pri Srbih in Bolgarih. Opisal je tudi njeno razširitev v srednjeevropskem prostoru: pri Čehih in Poljakih in njeno prenikanje v rusko pismenost. Dano temo iz starejše ruske literature je Murku priporočil Veselovski, ki je bil profesor zahodnoevropskih literatur na petrograjski univerzi. Okvirno zgodbo, ki je v zahodnih in vzhodnih literaturah obstajala v več verzijah, je Murko razlagal po migracijski teoriji kot parafrazo staroveškega motiva o hinavščini nezvestih žen. Polívka je na pismo s poslanim izvodom študije takoj odgovoril in leta 1891 objavil pozitivno recenzijo o tem v Masarykovi znanstveni reviji Athenaeum. ${ }^{9}$ Mogoče je tudi sklepati, da je Polívko z Murkom povezala filološka koncepcija slavistike po Jagiću, ki je postavljala v ospredje interpretacijo ljudskega slovstva in ki je za razliko od ruskega »slavjanovedenija« poudarjala kompleksno poznavanje duhovnih form slovanskega sveta. ${ }^{10}$ Polívka in Murko sta bila tudi povezana z dunajsko slavistiko. Polívka je leta 1882 na Dunaju zagovarjal doktorat in Murko je študiral slavistiko na dunajski univerzi pri Miklošiču ter se leta 1897 habilitiral iz predmeta slovanske filologije ter se posvečal zgodovini slovanskih literatur.

Znanstveno sodelovanja je kasneje preraslo v prijateljstvo. Obsežna korespondenca med Murkom in Polívko se je razvila po Murkovem prihodu iz Rusije. Študijsko bivanje od septembra 1887 do februarja 1889 se je Murka dotaknilo tako človeško kot znanstveno. Tudi Polívka se je študijsko izobraževal v Rusiji na koncu osemdesetih let, tudi zanj je bilo v znanstvenem pogledu bivanje v Rusiji zelo pomembno. V letih 1889-1890 je obiskoval predavanja znanih ruskih slavistov Pypina, Veselovskega, Tihonravova itd. Polívko je s slovenskim zanstvenikom povezovalo (na to je vplivalo delo Veselovskega) tudi skupno zanimanje za srednjeveško zabavno literaturo iz viteškega okolja, ki je prodirala iz nemškega jezikovnega okolja v slovenski prostor - kot t. i. ljudske knjige z bruncvikovsko snovjo ali pa za roman o Apollonu, tirskem kralju. Recepcijo tega romana $\mathrm{v}$ češki, poljski in ruski literaturi je Polívka analiziral v svoji raziskavi leta 1889 v Listih filoloških, ${ }^{11}$ kar je Murko pohvalil v svoji recenziji, izdani v Jagićevem Archivu für Slavische Philologie. ${ }^{12}$ Murko se je pozneje tudi sam posvetil tekstu o Apollonu Tirskem. ${ }^{13}$

\footnotetext{
${ }^{9}$ Polívka, Murko: Bugarski i srpski prijevod knjige o sedam mudraca, Athenaeum 8, 1891, 278-279; primerjaj tudi Jiř́ Polívka (1858-1933), ur. Gašparíková 2006.

${ }^{10}$ Primerjaj Zelenka 2003: 32; primerjaj tudi Kudělka 1984.

${ }^{11}$ Polívka, Román o Apollonovi králi Tyrském v literatuře české, polské i ruské, Listy filologické 16, 1889, 353-358, 416-435; isti, Dvě povidky v české literatuře v 15. století, Praha 1889; isti, Kronika o Bruncvikovi v ruské literatuře, Praha 1892.

12 Murko 1891: 308-311.

${ }^{13}$ Murko 1892: 405-421.
} 
V korespondenci Polívka in Murka ${ }^{14}$ navkljub prevladujočim osebnim tonom predstavljata poglede na slovanski svet. Že v svojem prvem pismu z dne 13. 8 . 1890 je Polívka komentiral Murkove kritične potopisne vtise iz Rusije. Polívki je šlo predvsem za objektivno razumevanje Rusije in njenih znanstvenih dosežkov, za študij ruske kulture in literature. Odklonil je politično nadrejeno pozicijo Rusov kot slovanskih vodij in zagovarjal kulturno izmenjavo, svobodo tiska, versko toleranco in demokratično širjenje informacij med posameznimi slovanskimi narodi. V pismu 13. 8.1890 piše Murku:

Srečen razvoj Rusije in sploh vseh slovanskih narodov je odvisen od zmanjšanja zunanjega pritiska: naj se osvobodi življenje naroda, naj se razvije svoboda duhovnega in kulturnega življenja, svoboda kritike in se bodo dogajali čudeži. ${ }^{15}$

V obsežnem pismu z dne 18. 8. 1890 - odgovoru Polívki na predhodno pismo - mu je Murko poskušal osvetliti svoje kritično stališče do Rusije. Bivanje v Rusiji mu je sprožilo številne dvome in tako spregovori o dveh podobah Rusije: Rusije na vasi in intelektualne Rusije, kot jo je spoznal v Moskvi in Petrogradu. Predvsem pa slika Rusijo kritično brez apriornega idealiziranja in mitiziranja, podobno kot jo je zarisal v svojih črticah ob vrnitvi. ${ }^{16}$ Pri tem opozarja na neustrezne predstave o ruski veličini, ki jih povezuje z lažnim panslavizmom in rusofilstvom. Izhaja tudi iz slovenskih razmer, v katerih je bil problem nekritičnega rusofilstva in panslavizma še vedno zelo aktualen:

Velika politika slovanstva méne tudi zanima, ker ravno ta se plete povsod v naše življenje. Posebno tukaj je treba kritike! Če bi jaz že bil nekaj ali pa bogat, da mi ne bi bilo treba misliti na bodočnost, napisal bi knjigo Der Panslavizmus. Beleuchtung eines Gespensts. ${ }^{17}$

Polívko je presenečal Murkov pozitiven odnos do češke kulture in literature, ki ga je slovenski znanstvenik izrazil že na začetku devedesetih let 19. stoletja v nekaterih študijah o koncepciji slovanske vzajemnosti v delu Kollárja in predvsem v spisu Deutsche Einflüsse, v katerem je analiziral drugonarodne vplive na češki narodni prerod. Med pisanjem se je posvetoval s češkimi literarnimi zgodovinarji - predvsem z Vlčkom in Jakubcem, ki sta prebirala njegovo študijo še v korekturah. Kontakt s Polívko je bil zanj zanesljiv vir informacij o čeških znanstvenih razmerah, posebej o situaciji na praški univerzi.

Najpomembnejša tema njunega dialoga izhaja iz novega koncepta slavističnih študij, saj je v tem obdobju postala pomembna razdelitev slavističnih področij, ki je zahtevala tudi nov način raziskovanja in poučevanja v slavističnih uni-

${ }^{14}$ Korespondenca Polívke Murku, ki se nahaja v Narodni in univerzitni knižnici v Ljubljani, je že bila izdana: Zelenková 2008b: 151-184.

${ }^{15}$ Polívka Matiju Murku v pismu dne 13. 8. 1890. Pismo se nahaja v Narodni in univerzitni knižnici v Ljubljani, fond M. Murko, št. sign. Ms 1119/1123.

${ }^{16}$ Članki so izhajali v Ljubljanskem zvonu leta 1889, kasneje jih je izdal v knjigi: Matija Murko, V provinciji na Ruskem, Ljubljana 1888, 88 s.

${ }^{17}$ Murko Polívki v pismu iz Dunaja, 18. 8. 1890. Pismo se nahaja se v Literárním archivu Památníku národního písemnictví (LA PNP) na Strahovu: fond M. Murko, spis 15/B/26. 
verzitetnih centrih. Tudi v Murkovi znanstveni usmerjenosti lahko opazimo podoben proces kot pri Polívki, ki je vodil od začetne široke usmerjenosti, ${ }^{18} \mathrm{k}$ primerjalnim študijam iz slovanskih literatur in potem $\mathrm{k}$ tematiki južnoslovanskih literatur ter končno do primerjalnega preučevanja posameznih nacionalnih literatur in ljudskega slovstva. Murko in Polívka sta razmišljala o razvoju nacionalnih filologij na srednjevropskih univerzah, predvsem na ozemlju tedanje avstoogrske monarhije. Novo pojmovanje slavističnega študija je pri slavistih dozorelo v željo po spremembi prav na koncu 19. stoletja.

Razvoj slavistike na obrobnih področjih habsburške monarhije (vključno s Češko) je povezoval filološke raziskave $\mathrm{z}$ narodnim gibanjem in njegovimi kulturno-političnimi ambicijami, ki so bile poskus strokovne in institucionalne specializacije. V vprašanju reorganizacije slovanskega seminarja in oblikovanja praške specializirane katedre za zgodovino češke literature so Polívkove predstave nasprotovale Jagićevemu razumevanju enotne slovanske filologije. Polívka je v pismu Murku z dne 24. 1. 1897 podrobno analiziral probleme, ki so kazali na vzpon njegove kariere. Razmišljal je tudi o možnih kandidatih za mesto bohemista na praški univerzi. Leta 1897 je namreč prišlo do nove razdelitve slovanske seminarja po Gebauerjevem predlogu, ki je računal z nastopom Jagićevega učenca Pastrneka na praško slavistiko.

Praški Slovanski seminar je bil razdeljen na tri oddelke: na starocerkveno slovanski oddelek na čelu s Pastrnekom, na oddelek za češčino, ki ga je vodil Gebauer in na oddelek za nove slovanske jazike in literature, ki ga je vodil Polívka. Ta je zagovarjal Vlčkovo kandidaturo, navkljub temu, da je Gebauer videl na tem mestu bohemista Josefa Hanuša. A Hanuševega dela Život a spisy Václava Bolemíra Nebeského (1896) niso hoteli priznati kot tekst, ki bi ustrezal habilitacijskim merilom.

V pismu 28. 1. 1897 se je Murko opredelil do nove podobe slavistike na Češkem s sintagmo »nazori o nalogah slavistike« in zagovarjal diferenciacijo stroke: delitev jezikoslovja in stare literarne zgodovine od nove (»po mojem je prišel čas za delitev lingvistike in stare literarne znanosti od nove«). ${ }^{19}$ Kot primer navaja lasten znanstveni razvoj, saj je kljub temu, da je bil Miklošičev in Heinzlov učenec, pozneje prešel v literaturo. V tem pismu se tudi opredeli do češke situacije: Polívki svetuje, naj na Filozofsko fakulteto v Pragi za predavatelja raje vzamejo Vlčka za češko literarno zgodovino, saj ima »širše obzorje po svetu «. ${ }^{20} \mathrm{Ob}$ tem za jezikoslovje in starejšo češko literaturo predlaga Pastrneka in samega Polívko.

\footnotetext{
${ }^{18}$ Zelenka poudarja, da je Murko izhajal iz Jagićeve teorije slavistike kot celote - enotnosti slovanske filologije, dane tremi medsebojno povezanimi področji: študijem slovanskih jezikov, slovanskih literatur in njihove zgodovine in »navad«: raziskovanjem folklore in etnološke tradicije (Zelenka 2005: 55).

${ }^{19}$ Murko Polívki v pismu iz Dunaja, 28. 1. 1897. Pismo se nahaja se v Literárním archivu Památníku národního písemnictví (LA PNP) na Strahovu: fond M. Murko, spis 15/B/26. ${ }^{20}$ Ibid.
} 
Murko ni napisal recenzije Hanušovega spisa za Archiv für slavische Philologie, je pa objavil pozitivno recenzijo Vlčkove monografije První novočeská škola básnická (1896), kar je tudi pomagalo, da se je Vlček leta 1898 habilitiral iz zgodovine češke in slovaške literature ter da so ga leta 1901 imenovali za izrednega profesorja.

V strukturo češke slavistike in bohemistike je Murko še enkrat posegel leta 1906, ko je 18. 12. 1906 svetoval Polívki, naj znotraj češke slavistike predavajo tudi o južnoslovanskih temah - k poučevanju starejše južnoslovanske literature je spodbujal tudi samega Polívko:

Priporočal bi Vam samo, da predavate Pasternek in Vi o starši jugoslovanski literaturi,

ki je do 12. stoletja itak del občne slavistike, potem pa še o srednjeveški srbski in hrvaški in tudi o dalmatinski duhovnosti. ${ }^{21}$

Na mesto predavatelja tudi iz novejših južnoslovanskih literatur predlaga bohemista in slavista Máchala. Posebno zanimivo je, da Murko predlaga Polívki, naj slovenski, hrvaški in srbski študentje opravljajo izpite v svojem jeziku tudi v Pragi, saj po njegovem mnenju češki slavisti, predvsem Polívka, te jezike dovolj obvladajo: »kar se pa slovenščine tiče, mislim, da jo vi lahko vsaj tako dobro izprašujete kakor na Dunaju Rešetar«. Polívki tudi svetuje, naj na fakulteti uradno pridobijo pravico za izpraševanje $\mathrm{v}$ teh jezikih. Kot izpraševalca predlaga prav samega Polívko. ${ }^{22} \mathrm{~V}$ tem pismu se tudi opredeli do skupnega termina »južnoslovanski jeziki in kulture«. Razume ga kot nadnarodno celoto v smislu Kollárjeve ideje, podrobneje pa idejo povezanosti južnoslovanskih literatur razloži v študiji Geschichte der ältern Südslawischen Literaturen iz leta 1908. Že v tem pismu sugerira Polívki, da bi vpeljali vse južnoslovanske jezike in literature na češko univerzo.

Pisma osvetljujejo tudi odnos Polívke in Murka do »patriarha« evropske slavistike V. Jagića in zapletena razmerja med dunajsko in praško univerzo. Jagić je urejal mednarodni časopis Archiv für slavische Philologie, osrednje slavistično glasilo, v katerega so prispevali slavisti iz srednjeevropskega prostora. V tem glasilu je Murko recenziral tudi veliko čeških znanstvenih dosežkov in o tem poročal Polívki: »Obljubil sem že lani Jagiću napisati o Vlčkovem in Macharovem spisu o Puchmajerju, potem o Masarykovem Havlíčku in Jakubcevem A. Mareku. ${ }^{23} \mathrm{~V}$ pismih Polívki je Murko kljub siceršnjemu velikemu spoštovanju do Jagića precej bolj kritičen do patriarha slavistike.

${ }^{21}$ Murko Polívki v pismu iz Gradca, 18. 12. 1906. Pismo se nahaja se v Literárním archivu Památníku národního písemnictví (LA PNP) na Strahovu: fond. M. Murko, spis 6/X/26.

${ }^{22}$ Ibid.

${ }^{23}$ Referati o knjigah so izšli v Jagićevem Archivu: M. Murko, J. Jakubec: Antonín Marek. Jeho život a působení i výzkum v literatuře české, Praha, 1896, J. Vlček: První novočeská škola basnická, Praha, 1896, Archiv für slavische Philologie 19, 1897, 622-627; M. Murko, J. Máchal: Ant. J. Puchmajer. Příspěvek k dějinám české literatury, Praha, 1895, Archiv für slavische Philologie 19, 1897, 619-622. 
Po razdelitvi Karlove univerze leta 1882 na češki in nemški del, torej v času, ko je v Pragi zrasla moderna pozitivistično orientirana generacija slavistov na čelu z Gebauerjem, je ostalo težišče slavističnega delovanja zaradi Jagićevega vpliva na Dunaju, kjer je študirala in se habilitirala večina evropskih slavistov, med njimi tudi M. Murko. V pismu Murku z dne 27. 7. 1907 se je Polívka ukvarjal s problemi nasledstva na praški bohemistiki, ki bi se po njegovem morala zaradi Vlčka usmeriti v moderno literarno zgodovino. Češkemu literarnemu zgodovinarju se po mnenju Polívke ni treba profilirati kot slavistu, a je zanj nujen študij češko-nemških kulturnih odnosov. A Polívka je hotel reformo tudi na jezikovnem področju: češki jezikoslovec - tu je računal s Smetánko kot z izrednim profesorjem - naj bi se poleg diahronega študija starocerkvene slovanščine usmeril tudi v raziskovanja sinhronega stanja zahodnoslovanskih jezikov, ki so »bolj pomembni kot znanje starocerkvene slovanščine. Gebauer tega ni zagovarjal in Smetánka se v tem kaže kot njegov učenec. Na tej stopnji bomo pazili, da bo Vlček postal /.../ redni profesor po Gebauerju in Smetánka izredni.« ${ }^{24}$ Po njegovem mnenju mora »česki jezikoslovec biti slavist, za češkega literarnega zgodovinarja pa to ni potrebno «. ${ }^{25}$

Po drugi strani pa je Murko poročal Polívki o usodnih trenutkih svoje univerzitetne kariere. Leta 1902 je bil sprejet kot profesor na slavistično katedro v Gradec. Postopek je bil zelo zapleten, kar opisuje v pismu Polívki 2. 2. 1902. O izbiri profesorja v Gradcu je odločala celotna evropska slavistična elita: »Jagića niso vprašali, zato pa Leskiena, Roscherja in morebiti še Nehringa ali drugih ljudi. ${ }^{26}$ Kako človeško obziren je bil do svojih kolegov, kaže njegov odnos do Štreklja, saj ni mogel razume, zakaj mu v Gradcu še niso dodelili profesure: »/.../ imam seveda častno dolžnost, da se zaradi njega takoj v fakulteti pokregam, kajti jaz bi ga seveda čim prej predložil .... $\ll^{27}$

Po prelomu stoletja prevladujeta v Polívkovih pismih kritičen ton in določena skepsa. Njegova očesna bolezen, zaradi katere ni mogel intenzivneje delati, se je poslabšala in o tem je pisal Murku. ${ }^{28}$ Začel je pripravljati slovanski material za novo izdajo Grimmovih Anmerkungen zu den Kinder- und Hausmärchen der Brüder Grimm, ${ }^{29}$ predaval je na univerzi, od leta 1896 je bil sopredstojnik Slovanskega seminarja, hkrati je vodil tudi Oddelek za nove slovanske jazike in literature. V korespondenci z Murkom z dne 26. 1. 1902 je pisal Polívka tudi o svoji bojazni, da ne bo potrjen za rednega profesorja, strah ga je bilo

${ }^{24}$ Jíř́ Polívka Matiju Murku v pismu z dne 27. 7. 1907. Nahaja se v Narodni in univerzitni knjižnici, fond M. Murko (št. sign. Ms 1119/1123).

${ }^{25}$ Ibid.

${ }^{26}$ Murko Polívki v pismu iz Gradca, 2. 2. 1902. Pismo se nahaja v Literárním archivu Památníku národního písemnictví (LA PNP) na Strahovu: fond M. Murko, spis 15/B/26.

${ }^{27}$ Murko Polívki v pismu iz Gradca, 2. 2. 1902.

${ }^{28}$ Polívka Murku v pismu z dne 20. 8. 1914. Pismo se nahaja v Narodni in univerzitni knjižnici v Ljubljane, fond M. Murko (št. sign. Ms 1119/1123).

${ }^{29}$ Anmerkungen zu den Kinder- und Hausmärchen der Brüder Grimm. Neu bearbeitet von Joh. Bolte und Georg Polivka, zv. I-V. Leipzig, 1913-1932. 
predvsem Gebauerjevega negativnega stališča. Dne 17. 12. 1902 je sicer dobil dekret rednega profesorja, a uradno je bil imenovan šele leta 1907. V letih 1908-1909, je, čeprav to ni bil njegov cilj, kot je trdil v pismu dne 26. 9. 1908, izvrševal funkcijo dekana. ${ }^{30}$ A kljub svoji strmo vzpenjajoči se karieri in delovnim uspehom se Polívka v pismih iz tega obdobja skeptično izraža o češki slavistiki: »Pri nas de facto ni širokega zanimanja za slovanski svet, ni prizadevanj po globljem razumevanju. Prevaja se veliko iz krasne literature, iz beletrije in poezije, a to je vse. $\aleph^{31}$ Te pesimistične stavke napiše Murku 3. 6 . 1906 in konča z izjavo: »V našem slovanstvu vlada samo bahanje. $\ll^{32}$ Po mnenju Polívke je kritično stanje českega poznavanja slovanskega sveta razkrila anketa o vzajemnosti v češkem tedniku Máj. Murko se je kot edini od tujih sodelavcev vključil vanjo z diskusijskim prispevkem, $v$ katerem se je opredelil do češkega nezanimanja za slovanstvo. ${ }^{33}$ Polívka je uvedel v svojem prispevku primer praške univerze, kjer »strokovna znanstvena predavanja o slovanskih jezikih in literaturah razumejo kot eksotične tako kot na primer o orientalni filologiji. ${ }^{34}$ Pritoževal se je Murku, da na Češkem ni poskrbljeno za vzgojo znanstvenega prirastka, da založbe v založniške programe ne vključujejo slovanskih naslovov, da niso dostopni niti zanesljivi slovarji iz vseh slovanskih jezikov. Zato ga niti ne preseneča, da "so vsa prizadevanja po tesnejših povezavah z vzhodnim svetom zaman . $^{35}$

Češko-slovenskih kulturnih odnosov se v korespondenci obeh slavistov neposredno dotikajo neuresničeni načrti za oblikovanje samostojne južnoslovanske katedre pri Filozofski in Pravni fakulteti na česki univerzi v Pragi. Tako je leta 1906 Polívka svojega slovenskega kolega obvestil o prošnji južnoslovanskih študentskih društev na Češkem, naslovljeni na senat Filozofske fakultete v Pragi, v kateri so ti zahtevali ustanovitev posebne katedre za južnoslovanske jezike in literature. Po mnenju Polívke si študenti niso prizadevali le za to, da bi na Karlovi univerzi stalno potekala predavanja o južnoslovanski pismenosti, temveč so hoteli, da bi bi bili državni izpiti priznani ne le za češko, temveč tudi za slovensko, hrvaško in srbsko govoreče študente. V pismu Murku z dne 16. 12. 1906 je podvomil v upravičenost peticije južnoslovanskih študentov, saj jim po njegovem mnenju primanjkuje resničnega zanimanja za lastno zgodovino in jezik in »zato je naš zbor prepričan, da se za to ni treba posebno prizadevati«. ${ }^{36}$ Zbor nasprotno ni bil proti temu, da se sprejemajo disertacije tudi v tujih jezikih, kar je, kot je Polívka sam napisal, »pripravljenost, ki se gospodom

\footnotetext{
${ }^{30}$ Polívka Murku v pismu z dne 26. 9. 1908.

${ }^{31}$ Polívka Murku v pismu z dne 3. 6. 1906.

32 Ibid.

${ }^{33}$ Slovanský postup. Anketa »Mája«. Máj 4, 1906, s. 562-563, 18. 5.

${ }^{34}$ Polívka Murku v pismu 3. 6. 1906. Pismo se nahaja v Narodni in univezitni knjižnici v Ljubljani, fond M. Murko (št. sign. 1119/1123).

${ }^{35}$ Ibid.

${ }^{36}$ Polívka Murku v pismu dne 16. 12. 1906.
} 
na drugih univerzah še zdaleč ne omogoči«. ${ }^{37}$ Ni soglašal s tem, da se iz univerzitetnega programa domačih pedagogov izpušča južnoslovanska tematika. Pri tem je spomnil na predavanja Pastrneka in Máchala, pozabil pa ni tudi na svoja (sam je predaval slovensko slovnico in slovenske dialekte skupaj s primeri iz starejše slovenske literature v poletnem semestru 1891). Stališče komisije, ki jo je oblikoval senat Filozofske fakultete v Pragi, je bilo negativno in zato zahtevi južnoslovanskih študentov niso ugodili. Iz analizirane korespondence se vidi, da se slovenska društva, ki so obstajala v Pragi, niso odrekla prvotnih predstav in načrtov. Dne 6. 1.1909 je Polívka pisal Murku o novi nameri teh društev (šlo je za društva Adria, Iliria in Klub slovenskih tehnikov), da bi se na češki univerzi oblikovali temelji slovenske univerze. Organizirale naj bi se posamezne slovenske katedre za znanost, umeščene na Pravni in Filozofski fakulteti, in to do tedaj, dokler ne bi dosegli takega števila habilitacij in profesur, da bi lahko v Ljubljani organizirali samostojno slovensko fakulteto. Za vzor naj bi služila italijanska pravna fakulteta, osnovana pri univerzi v Innsbrucku. Praška Filozofska fakulteta je tudi hotela zaposliti profesorja za slovenski jezik in literaturo. Murko naj bi predlagal glavne kandidate. Polívka je z načrti slovenskih študentskih društev v osnovi soglašal, a hkrati se je tudi zavedal, da je za njihovo uresničitev nujna sprememba češkega univerzitetnega zakona, to pa bi bi pomenilo, da se poleg češčine sprejme slovenščino kot učni jezik (JensterleDoležal 2005: 24-38): po njegovem pojmovanju naj bi se v slovenskem prostoru osnovala jugoslovanska univerza, predavalo bi se v vseh treh južnoslovanskih jezikih monarhije (oziroma po njegovih besedah dveh: slovenskem in srbskohrvaškem), kar naj bi avstrijske Jugoslavane samo zbližalo: ${ }^{38}$

Pri nas misli mnogo vplivnih ljudi, naj bi vseučilišče, oziroma fakulteta v Ljubljani ali tudi v Trstu, ako bi Lahi dobili tam jur. fakulteto, bila jugoslovanska. Jag. bi gotovo zastopal to stališče. Slovenski in srbsko-hrvaški jezik sta si tako podobna, da bi dijaki lahko poslušali predavanja, ${ }^{39}$ izpite pa bi delal vsak v svojem, ker bi se seveda tudi profesorji morali naučiti obeh jezikov. ${ }^{40}$

$\mathrm{V}$ istem pismu je skušal odgovoriti na Polívkovo vprašanje o možnih kandidatih za profesorja slovenske literature, ki naj bi bil »slovanski filolog s širšim obzorjem «, ${ }^{41}$ ki pa bi v takem primeru težko poučeval tako lingvistiko kot

\footnotetext{
${ }^{37}$ Ibid.

${ }^{38}$ Prizadevanja za slovensko univerzo so bila med Slovenci vse od leta 1848, že leta 1898 je Kranjski deželni zbor zahteval ustanovitev univerze s filozofsko, pravno in teološko fakulteto, ustanovil je univerzitetni sklad in razpisal dve štipendiji za Slovence, ki bi se hoteli habilitirati na pravni ali filozofski fakulteti v Avstriji in bi se zavezali, da bodo sprejeli profesuro na ljubljanski univerzi. (Podatki iz razstavnega kataloga Ustanovitev Univerze v Ljubljani v letu 1919, ki ga je izdala Univerza v Ljubljani ob občasni razstavi od decembra 2009 do februarja 2010,25.)

${ }^{39}$ Posamezne izraze v pismu je podčrtal sam M. Murko.

${ }^{40}$ Murko Polívki v pismu iz Gradca, 10. 1. 1909. Pismo se nahaja se v Literárním archivu Památníku národního písemnictví (LA PNP) na Strahovu: fond M. Murko, spis 6/X/26. ${ }^{41}$ Ibid.
} 
zgodovino književnosti. Tudi v primeru bodočega slovenista že izraža potrebo po specializaciji v znanstveni usmeritvi. Med drugimi predlaga tudi Prijatelja, Nahtigala in Grafenauerja:

I.../ dr. Prijatelj na Dvorni knjižnici na Dunaju je izvrsten literarni historik, ki pozna tudi staroslov. literature. Dr. Nahtigal na Zavodu za vzhodne jezike za ruščino je lingvist in stari filolog, o katerem se pa že dolgo nič ne slǐsi. ${ }^{42}$

Največ pa piše o I. Grafenauerju.

Oblikovanje slovenskih fakultet (ali slovenske univerze) v Pragi se na žalost ni uresničilo niti v drugem poskusu. Vzroki so bili politične narave. ${ }^{43}$ Razvoj češke oziroma slovenske inteligence in sploh na splošno slovanskega visokega šolstva $v$ habsburški monarhiji ni spadal med prioritete Dunaja. To dejstvo je postajalo jasno tudi Polívki, zato je pismo 6. 1. 1909 končal z besedami: »Zelo se bojím, da nam prinese to leto vsem, posebno avstrijskim Slovanom in tudi južnim, balkanskim novo bedo. $\aleph^{44}$

V korespondenci sta se ukvarjala tudi z vprašanjem Jagićevega naslednika na dunajski univerzi. V pismu 22. 5. 1908 je Polívka svojemu prijatelju napisal, da:

I.../ naši poslanci menda nameravajo poseči samo v primeru, če bi slučajno kandidiral Nemec /... Mislim, da bi najraje videli na Dunaju Nemca! Kam pa pridemo z nemškim terorjem na univerzah a furor teutonicus $v$ Avstriji nasploh. ${ }^{45}$

Polívka se je z Murkom strinjal v tem, da bo po Jagićevem odhodu pomen dunajske slavistike upadel. Mlajša generacija se je že ozko specializirala, tako da je manjkal Jagićev primerjalni pogled na slovanske kulture kot notranje idejno, konfesionalno in državnopravno diferencirano celoto. Polívka je v pismu z dne 26. 9. 1908 predlagal, da bi bil za slovanske literature imenovan Murko in za slovansko jezikoslovje češki slavist Vondrák, ki je bil na Dunaju najprej Jagićev student in od leta 1903 profesor slovanske filologije. Polívka in Murko sta se najbolj bala príhoda nemškega slavista Ericha Bernekerja, katerega »imenovanje bi bil težek udarec za vse slovanske avstrijske slaviste. $\aleph^{46}$ Berneker je deloval v Pragi od leta 1902 na nemškem delu univerze je leta 1909 prevzel mesto profesorja na wroclawski slavistični katedri.

\footnotetext{
${ }^{42}$ Murko Polívki, ibid.

${ }^{43}$ Zanimivo je, kako preroško danes zvenijo Murkove sugestije. V prvem profesorskem kolegiju za slovenistiko leta 1919 so bili sprejeti: redni profesor graške univerze dr. Rajko Nahtigal za splošno jugoslovansko filologijo, privatni docent graške univerze dr. Fran Ramovš za slovenski jezik in kustos Dvorne knjižnice na Dunaju dr. Ivan Prijatelj za zgodovino slovanskih literatur novejše dobe s posebnim ozirom na slovensko literaturo. (Podatki iz razstavnega kataloga Ustanovitev Univerze v Ljubljani v letu 1919, ki ga je izdala Univerza v Ljubljani ob občasni razstavi od decembra 2009 do februarja 2010, 35.)

44 Jiří Polívka Matiju Murku, ibid.

${ }^{45}$ Polívka Murku v pismu 22. 5. 1908.

${ }^{46}$ Polívka Murku v pismu 26. 9. 1908.
} 
V pismih lahko najtemo tudi pripombo o dodelitvi častnega doktorata Karlove univerze Matiju Murku leta 1909 - dani predlog je oblikoval in uveljavil prav J. Polívka.

Polívkova korespondenca z Murkom kaže českega slavista kot racionalno razmišljujoča znanstvenika, ki je posvetil življenje slavistični stroki. Bil je organizator, ki je skrbel za idejo slovanske vzajemnosti, »v njeno veliko poslanstvo je zares verjel in je pri tem imel za dolžnost /.../ izpolnjevati dediščino naših preporoditeljev.« (Horák 1935: 303)

Podobno se tudi Murko v pismih kaže kot moderen slovanski filolog, ki je rehabilitiral literarno zgodovino kot samostojno vedo o kritičnem spoznavanju kulturne preteklosti in jo je obenem izvzel s področja narodne mitologije. Njegov stik s Polívko je bil dolgotrajen, dotikal se je aktualnih problemov slavistične vede in organizacije slavističnega študija v raznih srednjeevropskih univerzitetnih centrih, ki naj bi delovali tudi kot protiutež dominantnemu Dunaju.

Znanstvenika sta se že zavedala »skupnega« evropskega prostora. Kot slavista sta čutila veliko mero odgovornosti in solidarnosti, ko sta spremljala razvoj slavističnih univerzitetnih središč v Evropi. Čeprav na začetku 20. stoletja nista uspela oblikovati mesta profesorja in tudi ne posebne katedre za slovenski jezik in literaturo na praški univerzi, so načrti obeh slavistov pomenili osnovo za poznejše sodelovanje po letu 1918 in za kasnejšo Murkovo naravno integracijo $\mathrm{v}$ češko kulturno in znanstveno okolje.

Ovrednotiti Murkove in Polívkove zasluge za osnovanje in razvoj evropske slavistike je skoraj nemogoče - njuno večplastno znanstveno in organizacijsko delovanje presega okvire enega predmeta, ene znanstvene teme: prav tako ni vezano samo na delovanje na eni ustanovi. Znanstvenika sta $\mathrm{z}$ analitičnimi posegi in izvirnimi, poglobljenimi detajli ustvarila vzporedna znanstvena opusa, v katerih sta slavistiko povezala s teorijo arealov - področij. Prav zaradi tematske odprtosti filoloških študij in meddisciplinarnih preseganj pomenita njuno delo in korespondenca inspirativen primer modernega pristopa $\mathrm{k}$ reševanju problemov v slavistiki na prelomu iz 20. v 21. stoletje. ${ }^{47}$

\section{LITERATURA}

Jiří BEČKKA, 1936: Matiáš Murko. Národní listy 76. 39 (9. febr.).

Jiří BEČKA, Anna ZELENKOVÁ, 2003: Výběrová bibliografie Matiji Murka. Murkova epocha slovanské filologie. Ur. M. Zelenka. Praha: Euroslavica. 123-168.

Viera GAŠPARÍKOVÁ (ur.), 2006: Jiři Polivka (1858-1933). Strážnice: Národní ústav lidové kultury.

${ }^{47}$ Slovaški del članka A. Zelenkove in citate J. Polívke je prevedla Alenka Jensterle-Doležal. 
Hana HLÔŠKOVÁ, Anna ZELENKOVÁ (ur.), 2008: Slavista Jiři Polívka v kontexte literatúry a folklóru. Bratislava - Brno: Katedra etnológie a kultúrnej antropológie FF UK - Slavistický ústav Jána Stanislava SAV - Česká asociace slavistů.

Jiří HORÁK, 1935: Jiří Polívka. 6. III. 1858 - 21. III. 1933. Ročenka Slovanského ústavu, zv. V-VII. Za tříletí 1932-1934. Praha: Slovanský ústav. 303.

Alenka JENSTERLE-DOLEŽAL, 2005a: Podobe slovenske književnosti v češki kulturi 19. stoletja. Jan Václav Lego (1833-1906). Ur. Jasna Honzak Jahič - Milada K. Nedvědová. Praha: Národní knihovna ČR - Slovanská knihovna. 24-38.

--, 2005b: Mit slovanske vzajemnosti pri Matiju Murku. Murko v myšlenkovém kontextu evropské slavistiky. Ur. Ivo Pospíšil - Miloš Zelenka. Brno: Slavistická společnost Franka Wollmana - Ústav slavistiky FF MU - Inštitut za slovensko literaturo in literarne vede ZRC SAZU. 136-148.

Milan KUDĚLKA, 1984: O pojeti slavistiky. Vývoj představ o jejím předmětu a podstatě. Praha: Academia.

Mathias MURKO, 1890: Die Geschichte von den sieben Weisen bei der Slawen. Wien.

- -, 1891: J. Polívka: Der Roman von Appolonius, König von Tyrus in der böhmischen, polnischen und russischen Literatur. Archiv für slavische Philologie 13, 308-311.

- -, 1892: Ruský překlad Appolllonia Týrského a Gest Romanorum. Archiv für slavische Philologie 14, 405-421. Rozpravy z oboru slovanského národopisu. Prev. Stanislav Petíra. Praha 1941, 198-214.

- -, 1908: Geschichte der ältern Südslawischen Literaturen. Leipzig.

Matyáš MURKO, 1949: Paměti. Praha: Fr. Borový.

Matija MURKO, 1962: Izbrano delo. Ljubljana: Slovenska matica.

Ivo POSPÍŠIL, 2005: Matija Murko a vybrané problémy literární vědy. Matija Murko v myšlenkovém kontextu evropské slavistiky. Ur. Ivo Pospíšil - Miloš Zelenka. Brno: Slavistická společnost Franka Wollmana - Ústav slavistiky FF MU - Inštitut za slovensko literaturo in literarne vede ZRC SAZU. 46-53.

Frank WOLLMAN, 1933-1934: Jiř́i Polívka. 6. 3. 1858-21. 3. 1933. Slavia 12, 589.

Miloš ZELENKA, 2005a: Matija Murko a česká literární komparatistika. Murkova epocha slovanské filologie. Ur. Miloš Zelenka. Praha: Euroslavica. 27-40.

- -, 2005b: O pojavu in značilnostih Murkove komparativne metode (na podlagi spisov Deutsche Einflüsse). Matija Murko v myšlenkovém kontextu evropské slavistiky. Ur. Ivo Pospíšil - Miloš Zelenka. Brno: Slavistická společnost Franka Wollmana - Ústav slavistiky FF MU v Brnu - Inštitut za slovensko literaturo in literarne vede ZRC SAZU. 54-64.

Anna ZELENKOVÁ, 2008a: K dejinám českej a stredoeurópskej slavistiky. Die slavischen Grenzen Mitteleuropas. Festschrift für Sergio Bonazza. Ur. Stefano Aloe. München: Verlag Otto Sagner. 189-198.

--, 2008b: Ku koreňom slovanskej filológie (Korešpondencia J. Polívku s M. Murkom). Slavista Jiři Polivka v kontexte literatúry a folklóru. Ur. Hana Hlôšková - Anna Zelenková. Bratislava - Brno: Katedra etnológie a kultúrnej antropológie FF UK - Slavistický ústav Jána Stanislava SAV - Česká asociace slavistů. 151-184. 
--, 2009: Medzi vzájomnostou a nevzájomnostou. Sondy do česko-slovenských literárnych vztahov. Praha - Nitra: Slovanský ústav AV ČR - Filozofická fakulta UKF.

Anna ZELENKOVÁ, Miloš ZELENKA, 2005: Matija Murko v dokumentoch (príspevok k dejiným európskej slavistiky). Matija Murko v myšlenkovém kontextu evropské slavistiky. Ur. Ivo Pospíšil - Miloš Zelenka. Brno: Slavistická společnost Franka Wollmana - Ústav slavistiky FF MU - Inštitut za slovensko literaturo in literarne vede ZRC SAZU. $148-187$.

\section{SLAVONIC PHILOLOGY IN SLOVENIAN-CZECH DIALOGUE BETWEEN M. MURKO AND J. POLÍVKA AT THE TURN OF THE $20^{\mathrm{TH}}$ CENTURY}

The paper examines relations between M. Murko (1861-1952) and J. Polívka (1858-1833), two major Slavonic scholars in Europe at the turn of the $20^{\text {th }}$ century. Their correspondence, as it has been preserved in the Manuscript Department of the National University Library, Ljubljana, and in the Literary Archives of the Museum of Czech Literature, Prague, yields helpful information on the exchange of views between the Slovenian scholar and his Czech counterpart. It was then that they laid foundations of modern Slavonic philology through integrating their knowledge of Slavonic folklore and common folk traditions. Their letters reveal that they reviewed and exchanged their books encouraging each other to publish their findings in journals.

Their written communication was initiated in 1890 by Murko, who, at the request of the Russian Slavonic scholar Sperensky, sent Polívka an offprint of his monograph Die Geschichte von den sieben Weisen bei der Slawen, and it ended with Polívka's death in 1933. Their contacts manifest a fruitful collaboration between Central European scholars at the time when the advancement of Slavonic studies in the peripheral regions of the Hapsburg Empire brought together philological research and national revival as well as cultural and political ambitions. Both researchers followed empiric positivism as Slavonic philology began splitting into separate national philologies.

Nothing other than the life and works of these two men reflect the alterations and peripeties of European Slavonic studies within a wide cultural and historical context, tracing the circulation of contemporary ideas at the crossroads where the Germanic West meets the Slavonic East. Through placing emphasis on comparative study, Murko and Polívka abandoned the romanticising concept of nationalist ideology, which isolated the Slavonic growth from "harmful" foreign influence. Among the events recorded in the correspondence, it is the year 1906 that deserves special attention, because, as Polívka's letters suggest, the Philosophical Faculty of Prague University then considered establishing a Slovenian Faculty in Prague and Murko was designated as Professor of Slovenian Language and Literature. Although this proposal failed to materialise, the authentic testimony of the researched correspondence is a valuable contribution to the institutional history of Slavonic studies, presenting the contemporary intellectual reflection upon Slavonic philology during its professional advancement at the turn of the $20^{\text {th }}$ century. 